Reprod. Nutr. Dévelop., 1981, 21 (1), 109-126.

\title{
The reproductive cycle in the male hedgehog (Erinaceus europaeus L.) : a study of endocrine and exocrine testicular functions
}

\author{
par M. SABOUREAU, B. DUTOURNÉ
}

Centre d'Éfudes Biologiques des Animaux Sauvages, C.N.R.S., Villiers-en-Bois, 79360 Beauvoir-sur-Niort, France.

\begin{abstract}
Summary. Seasonal changes in testicular and accessory gland weights, histological testicular structures, fructose and citric acid concentrations in two accessory glands and plasma testosterone levels were determined in adult male hedgehogs living in middle western France.

Testicular activity started in winter (from December to February) during the last part of the hibernation period. During this resumption period, testis weights as well as all the testicular structural features (Leydig cell volume; length, diameter and volume of seminiferous tubules) increased. These changes were correlated with similar variations in plasma testosterone concentrations and accessory gland features (weight, fructose and citric acid contents). However, maximal development of endocrine testicular function was reached about one month before the completion of spermatogenesis and the maximal development of androgen target organs. Testicular activity was high from February-March to AugustSeptember, according to the year. After the spring peak corresponding to the main breeding period, a decrease in testicular activity was always noted in May-June. The values of the testicular features then remained high or increased again and a second breeding period always occurred. Finally, involution began at the end of summer but the endocrine function of the testis decreased before the exocrine function. All the gonadal functions were depressed from September to November. Our results show that in middle western France, one of the southern-most countries characterized by a mild, temperate climate, the testis of Erinaceus europaeus $L$. is activated earlier and the breeding season lasts longer than in any of the other European countries cited in the literature.
\end{abstract}

\section{Introduction.}

The hedgehog (Erinaceus europaeus l..), an hibernating mammal, has a fairly wide distribution in Europe from the arctic circle to the 40th north parallel. Hibernation occurs during autumn and winter and ends at different times in the spring, depending on the latitude and the climate (Finland, end of April : Kristoffersson and Soivio, 1967 ; Sweden, end of March-beginning of April : Johansson and Senturia, 1972 ; Denmark, April-May : Walhovd, 1973, 1975 ; England, April : Morris, 1973 ; Germany, March : Herter, 1933 ; Switzerland, March-April : Berthoud, 1978 ; France, mid-February : 
Saboureau, 1979). Previous studies on the reproductive cycle in male hedgehogs (Marshall, 1911 ; Courrier, 1927 ; Allanson, 1934 ; Mombaerts, 1943 ; Girod and Curé, 1965 ; Saure, 1969) have been restricted to an analysis of testicular and accessory gland weight or histological change. All these studies showed that the hedgehog testis was quiescent in autumn under natural climatic conditions. Moreover, exocrine and endocrine testicular functions are activated at the end of hibernation as in many other hibernators (see review in Wimsatt, 1969). The time of the hedgehog breeding season is related to the latitude, being earlier and longer in southern than in northern countries (see review in Saure, 1969).

The earliest studies attempting to determine seasonal endocrine change used indirect methods such as the measurement of fructose or citric acid contents in the accessory glands (Mann, 1964). Mann (1963, 1964) studying the hedgehog showed that fructose and citric acid were secreted in separate accessory glands but he did not report any seasonal changes. Just recently, plasma testosterone concentrations have been accurately determined in seasonally breeding wild mammals (see review in Gustafson and Shemesh, 1976). In mammalian hibernators living under natural conditions, androgen has only been reported in bats (Racey, 1974 ; Racey and Tam, 1974 ; Gustafson and Shemesh, 1976).

To our knowledge, no quantitative studies have been done on testicular features, fructose or citric acid contents of accessory glands or on plasma testosterone level in the hedgehog. The purpose of the present investigation is to correlate the seasonal changes in these parameters in the hedgehog living in middle-western France. Such a study poses the problem of ecoregulation of the annual gonadal cycle of an hibernator widely distributed in Europe and living in a southern country.

\section{Material and methods.}

Animals. - Adult male hedgehogs were caught near the Chizé Forest (middlewestern France in the department of Deux-Sèvres; latitude $46^{\circ} 09^{\prime} \mathrm{N}$; longitude $0^{\circ} 24^{\prime} \mathrm{W}$ ). They were kept individually in $6 \mathrm{~m}^{2}$ surface-coated parks under natural conditions of light, temperature and rainfall with food (commercial dog food [Canina, Dusquesne-Purina] with chicken added) and water provided ad libitum.

In this study, the hedgehogs were used shortly after capture in the wild to reduce the effects of stress (e.g., capture, transport) and captivity.

Methods. - Experiments carried out over several years determined the following features : weight of genital organs, fructose and citric acid contents of genital accessory glands, plasma testosterone concentration and histological characteristics of the testis.

1. From 1969 to 1975 . The interval between each sacrifice varied greatly from one to several months, depending on capture, season and year (table 1). The animals were anaesthetized with ether and killed by decapitation. The testes, epididymides, accessory glands (seminal vesicle, internal and external prostates called « $A$ », « $B$ ») and « $C$ » glands, respectively, according to Mombaerts nomenclature, 1943) (fig. 1) were rapidly removed, weighed and frozen at $-25^{\circ} \mathrm{C}$. 
TABLE 1

Number of hedgehogs killed monthly from 1969 to 1975

\begin{tabular}{|c|c|c|c|c|c|c|c|c|c|c|c|c|}
\hline & $J$ & $\mathbf{F}$ & $M$ & A & $M$ & $\mathrm{~J}$ & $\mathrm{~J}$ & $A$ & $\mathrm{~S}$ & 0 & $N$ & $\mathrm{D}$ \\
\hline $1969 \ldots \ldots$ & $4 *$ & $4^{*}$ & $9 *$ & $5 *$ & & & 3 & & & $3 *$ & $3 *$ & $1 *$ \\
\hline $1970 \ldots \ldots$ & & & & & $2 *$ & $3 *$ & $5 *$ & & $2 *$ & $7 *$ & $5 *$ & $3 *$ \\
\hline $1971 \ldots \ldots$ & $2 *$ & $3 *$ & $4 *$ & $3 *$ & & & & & & & $3 *$ & \\
\hline $1972 \ldots \ldots$ & $3 *$ & & & & $6 *$ & $3 *$ & $4 *$ & $4 *$ & $4 *$ & & & \\
\hline$\overline{1973 \ldots \ldots}$ & $4 *$ & & $3 *$ & & $2 *$ & $2 *$ & & $3 *$ & & 1 & 3 & \\
\hline $1974 \ldots \ldots$ & 2 & 3 & 1 & 4 & 1 & 4 & & 2 & & 3 & 1 & 3 \\
\hline $1975 \ldots \ldots$ & & 3 & 1 & 5 & 1 & & & 3 & 1 & 1 & & \\
\hline
\end{tabular}

* Fructose and citric acid assays.

Urinary bladder

Vas deferens

Epididymis

Testis

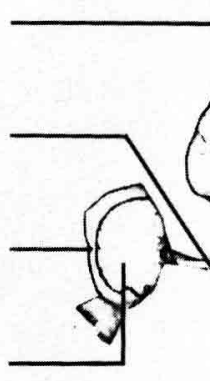

$+$



Seminal vesicle or gland "A"

Internal prostate or gland "B"

\section{External prostate or gland " $C$ "}

Urethral muscle with cowper's gland Penis

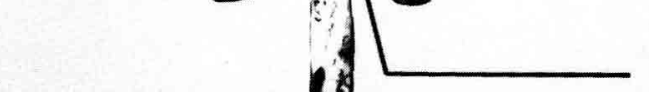
or gland " $D$ "

FIG. 1. - Description of the reproductive troct in the male hedgehog.

The hedgehog testes remain intraabdominal the whole year and the epididymis is closely applied to the festis. The reproductive tract is characterized by an extensive array of accessory glands, i.e. cranially and dorsally the seminal vesicles, ventrally the internal prostates, outside the pelvis the external prostate and embedded in the urethral muscle the Cowper's glands which, according to Mombaerts (1943), are « $A »,\langle B »,\langle C$ » and «D» glands, respectively. The vas deferens and ducts of these four pairs of glands run alongside the urethral tube, surrounded by a thick urethral muscle followed by a long penis. During the rutting season these accessory glands show striking changes. 
The fructose content of the « $A$ » glands was determined by the method of Lindner and Mann (1960). After the glands were ground with 80 p. 100 ethanol and centrifuged, the supernatant was evaporated to dryness. The residue was taken up in water and purified with appropriate quantities of $5 \mathrm{p} .100 \mathrm{SO}_{4} \mathrm{Zn}$ and $0.3 \mathrm{~N}, \mathrm{Ba}(\mathrm{OH})_{2}$ adjusted to the weight of the gland and the limits of the standard curve. The staining was revealed using the method of Roe (1934) described by Mann (1964) ; intensity was measured with a spectrophotometer (SAFAS).

The citric acid of the $4 B$ » glands was determined according to the method of Lindner and Mann (1960). The glands were ground with 15 p. 100 trichloracetic acid and centrifuged. After conversion to pentabromacetone, the citric acid in an aliquot of the supernatant was measured by colorimetric determination with a spectrophotometer (SAFAS).

As the seasonal variations were remarkably reproducible from year to year, we pooled the data gathered each month to obtain a better general view of the annual patterns.

2. During 1975. The seasonal profiles of testis volume and peripheral plasma testosterone levels were studied in 9 to 15 wild adult male hedgehogs per month. The animals were anaesthetized with Fluothane (ICl Pharma) but not killed. Blood was withdrawn from the jugular vein into heparinized tubes and centrifuged. Plasma from each sample was divided into several aliquots and immediately stored at $-25^{\circ} \mathrm{C}$ until assay.

At the same time, the testes which remained intraabdominal were measured in situ after laparotomy (lenght : I ; width : $w$; thickness : $t$ ) with callipers to the nearest $0.1 \mathrm{~mm}$. The assimilation of the testis to a spheroid (Setchell and Waites, 1964) gave us a good estimate of its volume, calculated by the formula :

$$
v=\frac{4}{3} \pi \times \frac{1}{2} \times \frac{w}{2} \times \frac{t}{2}
$$

Plasma testosterone $(T)$ was measured by radioimmunoassay using a testosterone RIA kit (Biomerieux, Fr.). In this assay, $5 \alpha$-dihydrotestosterone (DHT) was the only hormone which could interfere; DHT cross-reactivity for the antiserum supplied with the Biomerieux kit was 45 p. 100 . Consequently, the assay of a sample containing both T and DHT gave total T concentration plus 45 p. 100 of the DHT concentration. Moreover, a previous study in the hedgehog showed that the ratio DHT/T was always $<5$ p. 100 (table 2). So, assay of the total $(T+D H T$ ) effectively represented total testos-

TABLE 2

Comparison of plasma testosterone (T) and plasma $5 \alpha$-dihydrotestosterone (DHT) in 3 hedgehogs ot different times of the reproductive cycle

\begin{tabular}{|c|c|c|c|}
\hline & $\begin{array}{c}\text { Testosterone } \\
(\mathrm{ng} / \mathrm{ml})\end{array}$ & $\begin{array}{r}5 \alpha \text {-DHT } \\
(\mathrm{ng} / \mathrm{ml})\end{array}$ & $\begin{array}{l}\mathrm{DHT} / \mathrm{T} \\
\text { (p. 100) }\end{array}$ \\
\hline $\begin{array}{l}\text { Quiescence } \ldots \ldots \ldots \ldots \ldots \\
\text { Recrudescence } \ldots \ldots \ldots \ldots \\
\text { Activity } \ldots \ldots \ldots \ldots \ldots\end{array}$ & $\begin{array}{r}0.47 \pm 0.04 \\
5.62 \pm 0.30 \\
19.36 \pm 0.59\end{array}$ & $\begin{array}{l}0.015 \pm 0.005 \\
0.25 \pm 0.05 \\
0.45 \pm 0.06\end{array}$ & $\begin{array}{l}3.19 \\
4.45 \\
2.32\end{array}$ \\
\hline
\end{tabular}


terone concentration since the errors due to DHT interference was less than the inherent errors of the assay. $100 \mu \mathrm{l}$ of $\left[{ }^{3} \mathrm{H}\right]$-testosterone were added to each aliquot of plasma $(0.1 \mathrm{ml}$ during the activity period and $0.3 \mathrm{ml}$ during the resting period) and to two counting vials for recovery. The testosterone was then extracted twice with $5 \mathrm{ml}$ diethyl ether. After transfer into a tube, the ether layer was dried under nitrogen. One to $0.5 \mathrm{ml}$ of buffer was then added and the tube vortexed gently for $30 \mathrm{sec}$ to bring the testosterone into solution. A 0.5 to $0.2-\mathrm{ml}$ aliquot was added to a counting vial to estimate recovery, and a duplicate $0.1 \mathrm{ml}$ was put into a test tube for radioimmunoassay without chromatography. Duplicate standards were prepared by adding $0,15.6$, $31.2,62.5,125,250,500,1000 \mathrm{pg}$ of testosterone. $100 \mu \mathrm{l}$ of testosterone antiserum with immunoabsorbant (immunoabsorbant cellulosic-antitestosterone-3-(0-carboxymethyl)oxime serum albumin bovine) and $100 \mu \mathrm{l}$ of $\left[{ }^{3} \mathrm{H}\right]$-testosterone (AS $117 \mathrm{mCi} / \mathrm{mg}$ ) were added into all the tubes which were then incubated at $+37^{\circ} \mathrm{C}$ for $30 \mathrm{~min}$ and for one night at $+4^{\circ} \mathrm{C}$. They were centrifuged at $+4^{\circ} \mathrm{C}$ for $10 \mathrm{~min}$ and $0.5-\mathrm{ml}$ aliquots of the supernatant were added to the counting vials. After the vials were counted on a liquid scintillation counter, a computer (Digital PDP 11-40) with an appropriate program gave us the standard curve and the result for the unknown samples corrected for recovery and dilution expressed in $\mathrm{ng} / \mathrm{ml}$.

With this technique, the recovery rate was nearly 100 p. $100(95-100$ p. 100). The sensitivity, determined as the smallest detectable quantity of hormone, was about $100 \mathrm{pg}$ per tube. For testosterone of the same plasma pool assayed the same day or at different times, the precision of this method using intra-assay variability was 4 p.100 and using inter-assay variability, $10 \mathrm{p}$. 100. The accuracy of the radioimmunoassay was determined by adding different testosterone concentrations to the same plasma pool (table 3).

TABLE 3

Accuracy of the radioimmunoassay (Testosterone RIA kit, Biomerieux, Fr.) defermined by different testosterone concentrations added to $1 \mathrm{ml}$ of the same plasma pool ( $\mathrm{n}=3$ determinations)

\begin{tabular}{cc}
\hline $\begin{array}{c}\text { Testosterone added } \\
(\mathrm{ng})\end{array}$ & $\begin{array}{c}\text { Testosterone assayed } \\
(\mathrm{ng} / \mathrm{ml})\end{array}$ \\
\hline & \\
2 & $1.40 \pm 0.06$ \\
8 & $3.31 \pm 0.16$ \\
16 & $9.64 \pm 0.18$ \\
& $17.80 \pm 0.30$ \\
\hline
\end{tabular}

3. From October 1978 to October 1979. Every month, 3 to 7 animals were killed after Fluothane anaesthesia for histological study of the testis and, at the same time, blood was collected for assay as previously. The testes were taken and weighed ; the right testis was fixed in Bouin-Holland fluid, embedded in paraffin wax and then cut into $8-\mu \mathrm{m}$ sections. The nuclei were stained by means of Feulgen reaction $(15-\mathrm{min} \mathrm{HCl}$ hydrolysis at $+60^{\circ} \mathrm{C}$ ), and the cytoplasm and basement membrane of the seminiferous tubules were stained with blue alcian in acid medium (Hochereau-de Reviers, 1970). 
The seminiferous tubule diameters were measured with an ocular micrometer on 20 round tubule cross-sections per testis. The relative volumes of the seminiferous fubules, intertubular tissue and Leydig cells of a single testis were measured with a 25-point ocular integrator (Hennig, 1957) on 20 microscopic fields. The total volume of seminiferous tubules and the total volume of Leydig cells were calculated from relative volume and testicular weight. Seminiferous tubule length was calculated from the above data by the formula of Attal and Courot (1963):

$$
\text { Seminiferous fubule length }=\frac{\text { Total volume of seminiferous tubules } \times 4}{\pi \times(\text { seminiferous tubule diameter })^{2}} .
$$

Statistical analysis. - All the data were expressed as means \pm the standard error (SEM), and statistical comparison between the means were evaluated using the analysis of variance (F-test).

\section{Results.}

Seasonal weight variation in male genital organs.

1. Testis weight. - Between 1969 and 1975, testis weight showed (fig. 2) marked seasonal variation with two distinct periods :

- from January to September : testis weight was high (means $=3.3$ to $4.2 \mathrm{~g}$ ), and maximal values were observed in March, April and May as well as in August. However, in July there was a significant decrease in these values (April vs July : $P<0.01$ );



FIG. 2. - Seasonal changes in the weights of paired testes, paired epididymides and paired accessory glands, i.e. « $A$ », " $B$ " and " $C$ » glands, in adult male hedgehogs. (n) number of animals (data from 1969 to 1975 pooled monthly; for details see table 1 ). 
- from October to December : testis weight was minimal (means $=1.7$ to $2.3 \mathrm{~g}$ ) with the lowest values in November.

The increase in testis weight started in winter (December and January) and involution in early autumn (September). During these periods, the testes showed great individual variations. The percentage of increase in testis weight from seasonal rest to breeding season was about 200 p. 100.

2. Epididymis weight. - The weight of the epididymis (fig. 2) was very similar to the profile of testis weight. Epididymal weight was maximal from January to September (means $=0.61$ to $0.80 \mathrm{~g}$ ) and minimal from October to December (means $=0.34$ to $0.48 \mathrm{~g}$ ).

3. Accessory gland weight. - Seasonal changes in the weight of the three pairs of accessory glands, i.e. « $A$ », «B $B$ and « $C$ » glands (fig. 2 ), were strictly synchronized.

From October to January, the weights of the three pairs of accessory glands were minimal ( $\mathrm{A}$ » gland means $=2.2$ to $5.3 \mathrm{~g} ; 《 \mathrm{~B}$ » gland means $=0.5$ to $1.1 \mathrm{~g} ; 《 \mathrm{C}$ » gland means $=0.8$ to $1.8 \mathrm{~g}$ ). The glands were flat, quiescent, small and did not secrete.

In February, the accessory glands swelled rapidly with large individual variations. They were well vascularized and secretion products appeared in large quantities.

From March to August, accessory gland weights were very high, being multiplied by a coefficient from 10 to 20 . All the glands were hypertrophied with large amounts of secretion. During this period of maximal sexual activity, we observed :

- from March to May : a first activify period with the highest accessory gland weights ( $(\mathrm{A})$ glands $=18.7$ to $19.8 \mathrm{~g} ; « \mathrm{~B} »$ glands $=4.5$ to $5.7 \mathrm{~g} ;\langle\mathrm{C} »$ glands $=4.8$ to $6.1 \mathrm{~g})$;

— in June and July : a highly significant decrease (April vs June or July: $P<0.01$ ) as compared with the former activity period ( $(A)$ glands $=12.4$ to $10.9 \mathrm{~g} ; 《 B$ » glands $=3.4$ to $2.8 \mathrm{~g} ;$ « $C$ » glands $=4.2$ to $3.1 \mathrm{~g})$;

- in August : $a^{-}$slight but regular increase ( $A$ A $»$ glands $=12.5 \mathrm{~g}$; « $B$ » glands $=3.7 \mathrm{~g} ; \ll C »$ glands $=4.7 \mathrm{~g}$ ) which was not significant as compared to June or July ;

- in September : the weights of the accessory glands decreased slowly, the glands regressing in size but still showing residual secretions.

Seasonal changes in accessory gland weights paralleled testicular weights, except in winter (January-February) ; during preparation for the breeding season, they were out of phase : testicular weights increased a month or two earlier than accessory gland weights. Moreover, the accessory glands showed a marked decrease in June and July and a trend to a second maximum in August.

Seasonal changes in fructose and citric acid in two accessory glands.

In the hedgehog, fructose and citric acid, identified as normal constituents of the accessory glands, were secreted in separate glands, i.e. fructose in « $A$ » glands and citric acid in « $B$ » glands. The profiles of the two secretions reflected the testicular endocrine function, so we described them simultaneously (fig. 3) : 
- from October to January : fructose ( 50 to $700 \mu \mathrm{g} / \mathrm{g}$ in « $\mathrm{A}$ » glands) and citric acid (90 to $100 \mu \mathrm{g} / \mathrm{g}$ in «B 》 glands) showed the lowest concentrations which were often trace values:

- from March to August : fructose (4600 to $6000 \mu \mathrm{g} / \mathrm{g}$ in « A 》 glands) and citric acid (470 to $750 \mu \mathrm{g} / \mathrm{g}$ in « B » glands) showed high values in all animals. During this period corresponding to the breeding season, when the data were expressed as concentrations, two maxima (April and August) were clearly separated by a regular decrease in May-June; on the other hand, when the data were expressed as the contents of paired glands, the profile was similar to that previously described for the weights of these accessory glands;

- from September : fructose and citric acid concentrations regularly decreased, reaching the lowest values in October.

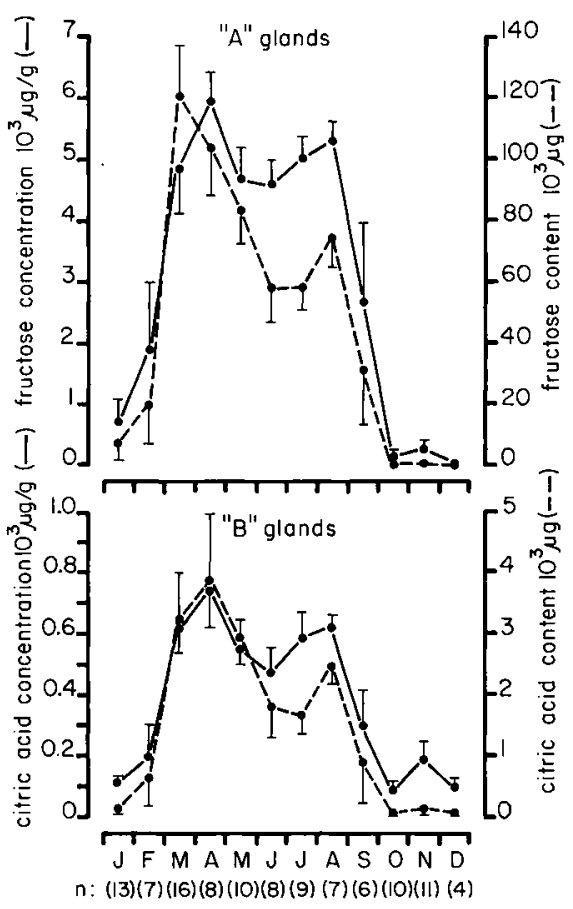

FIG. 3. - Seasonal changes of fructose in « $A$ » glands and citric acid in " $B$ " glands in odult male hedgehogs. (n) number of animals (data from 1969 to 1973 pooled monthly; for details see table 1 ). Results are given as content/paired glands (- - -) and as concentration $/ g$ of gland (-).

Seasonal changes in the weight and the content of fructose or cítric acid in « $A$ » glands and «B » glands, respectively, showed a similar trend. During the period of maximal activity, two peaks were clearly observed, indicating that testicular endocrine secretion was continuous but fluctuating in intensity.

Seasonal changes in testis volume and plasma testosterone level.

1. Testis volume. - Annual changes in testis volume (fig. 4) were similar to the variations in testis weight previously described. However, the decrease of testis volume in June was not statistically significant. 
FIG. 4. - Annual changes in paired testis volumes (- - -) and plasma testosterone level (-) in adulf male hedgehogs taken from their natural environment during 1975. (n) number of animals.

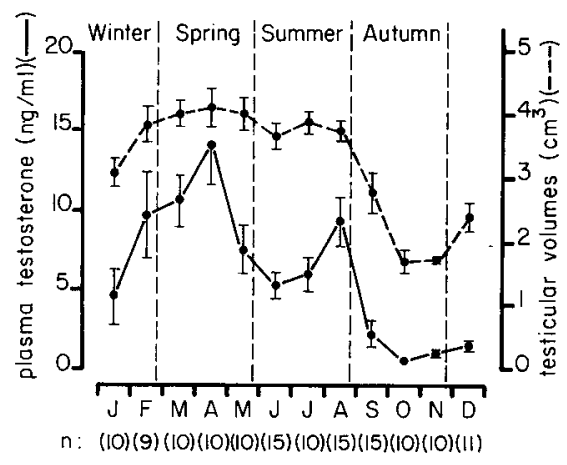

2. Plasma testosterone level. - Plasma testosterone in adult male hedgehogs recently taken from their natural environment showed a seasonal change (fig. 4) :

- from October to December : plasma testosterone levels were the lowest of the year (October : $0.56 \pm 0.05 \mathrm{ng} / \mathrm{ml}$; November : $1.02 \pm 0.15 \mathrm{ng} / \mathrm{ml}$; December : $1.54 \pm 0.36 \mathrm{ng} / \mathrm{ml})$;

- in January : plasma testosterone concentrations $(4.52 \pm 1.59 \mathrm{ng} / \mathrm{ml})$ increased significantly (November vs January : $\mathrm{P}<0.05$ ) :

- from February to April : plasma testosterone reached maximal levels $(9.75 \pm 2.6 \mathrm{ng} / \mathrm{ml}$ to $14.11 \pm 2.55 \mathrm{ng} / \mathrm{ml})$ with a peak in April ;

— in May : plasma testosterone decreased significantly (April vs May : $P<0.05$ ) and stayed at a mid-level until July (June : $5.23 \pm 0.78 \mathrm{ng} / \mathrm{ml}$; July : $5.88 \pm 0.80 \mathrm{ng} /$ $\mathrm{ml}$; April vs June or July : $\mathrm{P}<0.01)$;

- in August : there was a second testosterone peak $(9.30 \pm 1.46 \mathrm{ng} / \mathrm{ml}$; June vs August : $P<0.05$ ) comparable in intensity to the first peak observed in spring but shorter ;

- at the end of summer in September : plasma testosterone levels decreased rapidly $(2.23 \pm 0.72 \mathrm{ng} / \mathrm{ml})$ and significantly (August vs September $: \mathrm{P}<0.01)$.

The endocrine testis function thus starts again in the hedgehog befween December and January before the hibernation period has ended. The maximal testosterone levels show a biphasic pattern with an important spring peak and a shorter but regular summer peak ; these two peaks correspond to the two rutting periods observed in middle-western France.

Histological study of the testis (October 1978 to October 1979).

1. Morphology. - The study of the characteristic phases of seasonal gonad activity is illustrated in Plate I (figs. 1-4).

a) Resting period (Pl. I, fig. 1). In autumn, the interstitial tissue had regressed (Leydig cells aggregated in blocks with little cytoplasm; minimum-sized nuclei); the seminiferous tubules had a minimal diameter $(160$ to $170 \mu \mathrm{m})$ and contained only primary spermatocytes. 



PLATE I

Histological pattern in the adult male hedgehog testis throughout the annual reproductive cycle.

$(8 \mu \mathrm{m}$ sections $-\times 190)$.

FIG. 1. - November (resting period), FIG. 2. - February (resumption period), FIG. 3. - April (breeding season), FIG. 4. - September (regression period.) 
b) Resumption period (PI. I, fig. 2). From the end of December to February, the interstitial tissue was well developed (Leydig cells with large amount of cytoplasm and round nuclei); the seminiferous tubules increased greatly in size (180 to $210 \mu \mathrm{m})$ and showed intense spermatogenesis with numerous spermatids and sometimes spermatozoa. During these two months, there were great individual variations from wholly inactivated to wholly activated testis.

c) Breeding season (PI. I, fig. 3). In spring and the beginning of summer, the interstitial tissue reached its maximal size and all the seminiferous tubules (200 to $230 \mu \mathrm{m}$ ) contained mature spermatozoa.

d) Regression period (PI. I, fig. 4). In the late summer, the interstitial tissue decreased significantly in size, but some Leydig cell areas were still large ; spermatogenesis began to decrease but the tubules $(170$ to $200 \mu \mathrm{m})$ still contained numerous mature spermatozoa. As in January-February, there were large individual variations.

2. Seasonal variation in several structural characteristics.

a) Seminiferous tubules.

- Changes in total volume. The total volume of the seminiferous tubules (fig. 5) reached a maximum in spring, then decreased until September. The increase started in autumn (October vs December : $P<0.05$ ). The highest level was reached from February to May (November vs February : $P<0.01$ ). After a first decrease in June (May vs June : $P<0.01$ ), we observed a plateau in July and August and another decrease in September (July vs September : $P<0.01$ ).



FIG. 5. - Seasonal changes in right testis weight and total volume of seminiferous tubules.

(n) number of animals (data from October 1978 to October 1979).

These changes were well correlated with the testis weight (fig. 5) which showed a clearly marked seasonal profile characterized by low values from September to November and high values from February to August during the period of this study (1978-1979). 
- Changes in diameter. The seminiferous fubule diameters (fig. 6) were maximal in spring, then decreased; the minima were reached in September. The diameters increased from December to March (November vs March : $P<0.01$ ). The maxima occurred from March to May. After a first decrease in June (May vs June: $P<0.05$ ), a plateau was reached in July and August and involution occurred in September (July vs September : $p<0.01$ ).

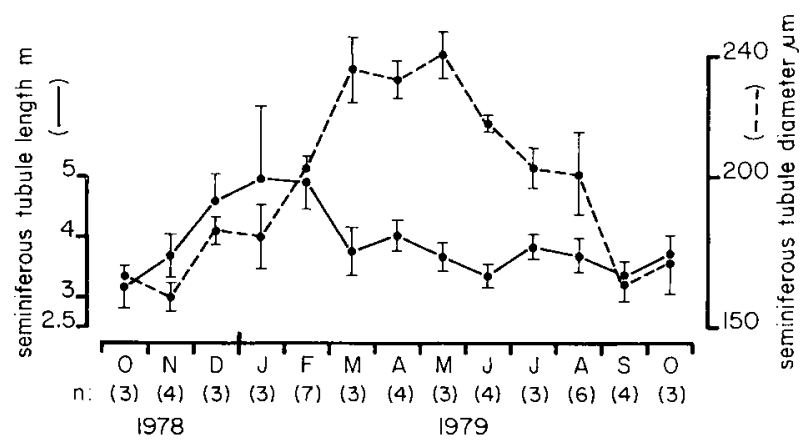

FIG. 6. - Seasonal changes in the length and the diameter of seminiferous fubules.

(n) number of animals (data from October 1978 to October 1979).

- Changes in length. Seminiferous tubule length (fig. 6) increased as early as November, reached a maximum from December to February (October vs December, February : $P<0.05)$, then decreased and reached a minimum in June, August and September (February vs June, August, September : $P<0.05$ ).

b) Interstitial tissue. The total Leydig cell volume (fig. 7) increased from December to April (November vs April : $P<0.01$ ). The values remained high from February to July and decreased in August (July vs August : $P<0.05$ ). Involution was maximal in September, October and November.

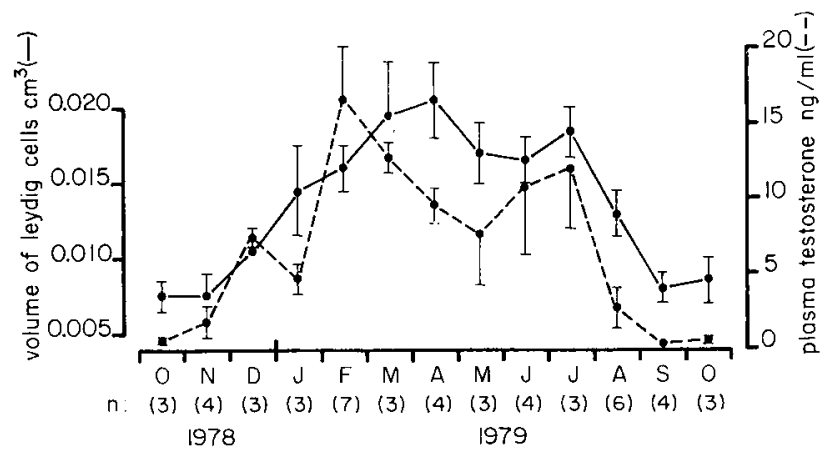

FIG. 7. - Seasonal changes in Leydig cell volume and plasmo testosierone concentration.

(n) number of animals (data from October 1978 to October 1979). 
During the same period (October 1978-October 1979), these changes paralleled the plasma testosterone concentrations (fig. 7) which were low in autumn and high from February to July.

\section{Discussion.}

The present results show that the highest testicular weight occurs when the seminiferous tubule diameter (which reflects spermatogenetic activity) and plasma testosterone level are maximal. The same correlations have been previously noted in the mole (Racey, 1978). Gonadal weight variations reflect changes in seminiferous tubule volume ; these variations are due to the remarkable flexibility of the tubule which can alter its diameter and length. On the other hand, the interstitial tissue is little related to testis weight since the Leydig cell-seminiferous tubule volume ratio is $1: 10$.

During the resumption period (from December to February), all the testicular structural features (Leydig cell volume; length, diameter and volume of seminiferous tubules) and plasma testosterone concentration begin to increase simultaneously. An interval of about one month was noted between maximal Leydig cell volume, plasma testosterone level, seminiferous tubule length (February) and maximal seminiferous tubule diameter (March). The hormono-dependent contractility (Hovatta, 1972) of myoid cells in the wall of the seminiferous tubules (Hermo, Lalli and Clermont, 1977 ; Bustos-Obregon and Holstein, 1973) may explain why maximal elongation occurs prior to maximal diameter. Furthermore, it was shown by autoradiographic technique that about one month elapses between the beginning of spermatogonial division and the completion of spermiogenesis (Dutourné, in preparation). From these results, the interval between maximal length and maximal diameter may be partly understood. During this period, the gradual increase in Leydig cell volume is probably due to nuclear and cytoplasmic hypertrophy, as in the hamster (Vendrely, Guérillol and Da Lage, 1972) and the red deer (Hochereau-de Reviers and Lincoln, 1978). All the features studied show high values from February to May. Thus, testis weight as well as volume, length and diameter of the seminiferous tubules shows a first significant decrease in June (compared with the peak), followed by slight changes from June to August with involution occuring between August and September. Elevated values for Leydig cell volume and plasma testosterone (fig. 7) were noted from February to July in spite of a diminution in May-June, while involution started in July or August, depending on the year. Therefore, the endocrine function begins to regress in the testis before the exocrine function.

During the resting period (from September to November) testis exocrine activity does not cease entirely since a few meiotic divisions are seen (primary spermatocytes in leptotene or pachytene phase). This is in opposition to many other seasonal breeders such as the mole (Allanson, 1963), roebuck (Short and Mann, 1966), ferret (Ishida, 1968), red-deer (Lincoln, 1971), stoat (Gulamhusein and Tam, 1974), polecat, marten, stone-marten (Audy, 1976) and red fox (Joffre, 1976) in which spermatogenesis regresses almost completely.

In the hedgehog, these testicular histological parameters show activation during the winter hibernation period with a more rapid development of the interstitial tissue 
than of spermatogenesis, while in late summer the interstitial tissue involutes before spermatogenesis. During the breeding season, the development of these two parameters is synchronized in March, while in June the size of the seminiferous tubules decreases.

To our knowledge, this paper reports for the first time a year-round correlation of hedgehog testis weight and histology, accessory gland weight and biochemistry as well as peripheral testosterone concentration. As testis weight, whose maximum is twice as much as its minimum, accessory gland weight also undergoes marked seasonal fluctuation (Allanson, 1934 ; Saure, 1969 ; Saboureau and Peyre, 1970). Moreover, the determination of fructose and citric acid contents in hedgehog accessory glands, which are related to the concentrations of circulating androgens (Lindner and Mann, 1960), are good criteria for testing the accuracy of periods of maximal activity and quiescence. The present data complete previous results (Saboureau and Peyre, 1970 ) and show that the seasonal profiles of accessory gland weight and of fructose (« A » glands) and citric acid (« B » glands) contents are closely correlated. Moreover, these substances reach maximal values during the observed periods of rut and show clearly a biphasic pattern of sexual activity. The determination of plasma testosterone contributes to our knowledge of the seasonal endocrine activity rhythm of the testis. Individual levels of peripheral testosterone exhibit a wide range : from 0.4 to $1.0 \mathrm{ng} / \mathrm{ml}$ during the resting period and 10 to $14 \mathrm{ng} / \mathrm{ml}$ during maximal sexual activity with values sometimes higher than $20 \mathrm{ng} / \mathrm{ml}$. These values agree with previous studies on captive hedgehogs (Saboureau and Boissin, 1978a, b). There is no data on annual testosferone levels in hibernators (Racey, 1974 ; Racey and Tam, 1974 ; Gustafson and Shemesh, 1976), except in bats. The high testosterone levels before and during hibernation in bats are difficult to compare with those of the hedgehog in which the testosterone concentrations peak every year between February-April and July-August. These peaks are in phase with the two periods of rut observed every year in middlewestern France (Saboureau, 1979). A regular decrease of testicular activity in June, as previously shown by the fructose or citric acid contents in accessory glands, is confirmed by the determination of plasma testosterone levels. This biphasic pattern of annual testosterone secretion is also found in many mammalian or avian species : stoat (Gulamhusein and Tam, 1974), badger (Maurel, Joffre and Boissin, 1977), roebuck (Sempéré, 1978), ferret (Boissin-Agasse and Boissin, 1979), duck (Garnier and Attal, 1970 ; Garnier, 1972 ; Assenmacher, 1974). According to the hypothesis of Assenmacher (1974), this biphasic pattern of the testicular endocrine cycle would be controlled by an hypothefical endogenous « circasemestrial clock ».

The onset of the hedgehog breeding season in Europe varies greatly with the latifude from north to south (see review in Saure, 1969). In Finland (Suomalainen, 1953 ; Saure, 1969) and Poland (Skowron and Zajaczek, 1947) the testis is activated later than in south European countries (Herter, 1938 ; Schütz, 1954, 1956 ; Marshall, 1911 ; Allanson, 1934 ; Saboureau and Peyre, 1970), and testicular activity is brief with only one breeding period per year in July (Saure, 1969). On the contrary, in middle-western France, one of the southern-most countries, testicular activity begins the earliest and lasts the longest, so there are two regular breeding periods.

The temporal relations between testicular activity and hibernation in hibernating mammals have been studied extensively (see review in Wimsatt, 1969). In the hed- 
gehog, testicular inactivity appears in autumn and corresponds to the beginning of hibernation (Saboureau, Laurent and Boissin, 1979), but testicular renewal starts during the last part of the hibernation period. This anticipated preparation during the winter for the spring breeding period has been shown in many other hibernators (see review in Wimsatt, 1969) and in the bear which is not a true hibernator (Mc Millin ef al., 1976). Some data show that neuroendrocrine activity appears during hibernation. In the hedgehog, the activation of pituitary cells producing $\mathrm{LH}$ and FSH starts as early as January (Girod and Curé, 1965) ; in the garden dormouse, appreciable increasing amounts of LRH are observed in the median eminence during hibernation (Richoux and Dubois, 1976). Secretion pulses seem to occur during spontaneous arousal (Dussart and Richoux, 1973), and consequently the increased activity may be either facilitated by or dependent on increased spontaneous arousals occurring at that time (Racey, 1974). Popovic (1960) states that the gonadal activation does not hinder the continuation of hibernation, while Hoffman (1964) thinks that hibernation is inconsistent with increased plasma LH levels. According to Pengelley and Asmundson (1974), spring arousals might be endogenous events caused by external conditions and so become synchronized with those conditions. Thus, endocrine recrudescence of the testis may be an endogenous process in the hedgehog as in the hamster ( $\mathrm{Smit-Vis}$ and Akkerman-Bellaart, 1967 ; Reiter, 1968, 1972 ; Hoffmann, 1973, 1978). However, environmental factors may modulate this phenomenon. In such a case, long days or increase in temperature and/or food availability may speed up the process of recrudescence. For instance, the sudden rise in ambient temperature noted in December 1978 could account for the significant increase of plasma testosterone concentration observed (fig. 7).

Therefore, further experiments are needed to determine if there is an endogenous rhythm and/or what environmental factor alone or association of factors is most important in testicular regulation in the hedgehog.

Reçu en juillet 1980.

Accepté en septembre 1980,

Acknowledgements. - This work was supported by a grant from the "Centre National de la Recherche Scientifique (ATP Ecophysiologie Animale) », Contract No. 1324. The authors thank Dr. M. T. Hochereau-de Reviers for her assistance and criticism of the manuscript.

Résumé. Les variations saisonnières du poids des testicules et des glandes annexes, des concentrations en fructose (vésicule séminale : glande $A$ ) et en acide citrique (prostate interne : glande $B$ ) et de la testostéronémie ont été déterminées chez le Hérisson mâle adulte vivant dans le Centre Ouest de la France. L'évolution des structures histologiques testiculaires (volume des cellules de Leydig ; longueur, diamètre et volume des tubes séminifères) a été également considérée.

La reprise des activités endocrine et exocrine du testicule est située durant l'hiver (entre les mois de décembre et février) tandis que l'animal hiberne. La testostéronémie des valeurs élevées, voisines du maximum annuel, dès le mois de février, un mois environ avant la fin des processus spermatogénétiques ou du développement maximal des glandes annexes. L'activité testiculaire est importante de la fin de l'hiver (février-mars) à la fin de l'été (aout-septembre). Après le pic printanier qui correspond à la période principale 
de reproduction, on observe, constamment, une diminution de l'activité testiculaire au cours des mois de mai ou juin. La reprise estivale du fonctionnement gonadique est plus ou moins importante selon les années ; celle-ci est concomitante de la seconde période de reproduction. Au cours de l'involution testiculaire, la diminution de l'activité endocrine précède celle de la fonction exocrine. De septembre à novembre, le repos sexuel est complet.

La comparaison de nos résultats à ceux fournis par la littérature montre que le Hérisson vivant dans le Centre Ouest de la France, une des régions les plus méridionales de la distribution géographique de l'espèce, présente l'activation du fonctionnement testiculaire la plus précoce et la plus longue période de reproduction.

\section{References}

ALLANSON M., 1934. The reproductive processes of certain mammals. VII. Seasonal variation in the reproductive organs of the male hedgehog. Phil. Trans. roy. Soc. London, ser. B, 223, 277-303.

ALLANSON M., 1963. The reproductive tract of prepubertal and mature male moles during the anoestrus. J. Endocr., 26, 9-10.

ASSENMACHER I., 1974. External and internal components of the mechanism controlling reproductive cycles in drakes, 197-248. In PENGELLEY E. T., Circannual clocks, Acad. Press, New York.

ATTAL J., COUROT M., 1963. Développement testiculaire et établissement de la spermatogenèse chez le taureau. Ann. Biol. anim. Bioch. Biophys., 3, 219-241.

AUDY M. C., 1976. Le cycle sexuel saisonnier du mâle des Mustélidés européens. Gen. comp. Endocr., $30,117-127$.

BERTHOUD G., 1978. Note préliminaire sur les déplacements du hérisson européen (Erinaceus europaeus L.). Terre et Vie, 32, 73-82.

BOISSIN-AGASSE L., BOISSIN J., 1979. Variations saisonnières du volume testiculaire et de la testostérone chez deux mustélidés : le furet (Mustela furo L.) et le Vison (Musfela vison S.). J. Physiol. Paris, 75, 227-232.

BUSTOS-OBREGON E., HOLSTEIN A. F., 1973. On structural patterns of the lamina propria of human seminiferous tubules. Z. Zellforsch, 141, 413-425.

COURRIER R., 1927. Etude sur le déterminisme des caractères sexuels secondaires chez quelques mammifères à activité testiculaire périodique. Arch. Biol., 37, 173-333.

DUSSART G., RICHOUX J.-P., 1973. Régulation de la fonction génitale chez le lérot. Action des hormones gonadotropes sur les activités monoamine oxydasiques diencéphaliques et sur les glandes génitales durant l'hibernation. Ann. Endocr. Paris, 34, 115-132.

GARNIER D. H., 1972. Etude de la fonction endocrine du testicule chez le canard pékin au cours du cycle saisonnier. Aspects biochimique et cytologique. Th. Doct. ès sci., Univ. Paris, 129 pp.

GARNIER D. H., ATTAL J., 1970. Variations de la testostérone du plasma testiculaire et des cellules interstitielles chez le canard pékin au cours du cycle annuel. C. R. Acad. Sci. Paris, Sér. D, 270, 2472-2475.

GIROD C., CURÉ M., 1965. Ełude des corrélations hypophyso-testiculaires au cours du cycle annuel chez le hérisson (Erinaceus europaeus L.). C. R. Acad. Sci. Paris, 261, 257-260.

GULAMHUSEIN A. P., TAM W. H., 1974. Reproduction in the male stoat, Mustela erminea. J. Reprod. Fert., 41, 303-312.

GUSTAFSON A. W., SHEMESH M., 1976. Changes in plasma testosterone levels during the annual reproductive cycle of the hibernating bat, Myotis lucifugus lucifugus with a survey of plasma testosterone levels in adult male vertebrates. Biol. Reprod., 15, 9-24.

HENNIG A., 1957. Das problem des Kern messung. Eine Zusammenfessung und Erweiterung der mikroskopischen Messtechnik. Mikroskopie, 12, 174-203.

HERMO L., LALLI M., CLERMONT Y., 1977. Arrangement of connective tissue components in the walls of seminiferous tubules of man and monkey. Am. J. Anat., 148, 433-446.

HERTER K., 1933. Gefangenschaftsbeobachtungen an europäischen igeln II. Z. Saügetierkunde, 8, 195-218.

HERTER K., 1938. Biologie der europäischen Igel. Monogr. Wildsäugetiere, 5. Leipzig., 222 pP.

HOCHEREAU-de REVIERS M. T., 1970. Efude des divisions spermatogoniales et du renouvellement de lo spermatogonie-souche chez le taureau. Th. Doct. ès sci., Univ. Paris, 134 pp. 
HOCHEREAU-de REVIERS M. T., LINCOLN G. A., 1978. Seasonal variation in the histo ogy of the testis of the red deer, Cervus elaphus. J. Reprod. Fert., 54, 209-213.

HOFFMAN R. A., 1964. Speculations on the regulation of hibernation. Ann. Acad. Sci. fenn., ser. A IV, 71, 199-216.

HOFFMANN K., 1973. The influence of photoperiod and melatonin on testis size, body weight, and pelage colour in the Djungarian hamster (Phodopus sungorus). J. comp. Physiol., 85, 267-282.

HOFFMANN K., 1978. Photoperiodic mechanism in hamsters : the participation of the pineal gland, 94-102. In ASSENMACHER I., FARNER D. S., Environmentol endocrinology, Springer Verlag, Berlin.

HOVATTA O., 1972. Effect of androgens and antiandrogens on the development of the myoïd cells of the rat seminiferous fubules (organ culture). Z. Zellforsch, 131, 299-308.

ISHIDA K., 1968. Age and seasonal changes in the testis of the ferret. Arch. histol. jap., 29, 193-205.

JOFFRE M., 1976. Puberté et cycle génital saisonnier du renard mâle (Vulpes vulpes). Ann. Biol. anim. Bioch. Biophys., 16, 503-520.

JOHANSSON B. W., SENTURIA J. B., 1972. Seasonal variations in the physiology and biochemistry of the European hedgehog (Erinaceus europoeus) including comparisons with non-hibernators, guinea-pig and man. Acta physiol. scand., Suppl. 380, 1-159.

KRISTOFFERSSON R., SOIVIO A., 1967. A comparative long-term study of hibernation in Finnish and German hedgehogs in a constant ambient temperature. Ann. Acad. Sci. fenn., ser. A. IV, 122, 1-23.

LINCOLN G. A., 1971. The seasonal reproductive changes in the red deer stag. (Cervus elaphus). J. Zool., 163, 105-123.

LINDNER H. R., MANN T., 1960. Relationship between the content of androgenic steroids in the testes and the secretory activity of the seminal vesicles in the bull. J. Endocr., 21, 341-360.

MCMILLIN J. M., SEAL U. S., ROGERS L., ERICKSON A. W., 1976. Annual testosterone rhythm in the black bear (Ursus americanus). Biol. Reprod., 15, 163-167.

MANN T., 1963. Biochemistry of the prostate gland and its secretion. Biology of the prostate and related tissues. Nat. Concer Inst. Monogroph., 12, 235-251.

MANN T., 1964. The biochemistry of semen and the male reproductive tract. Methuen and Co. LTD, London.

MARSHALL F. H. A., 1911. The male generative cycle in the hedgehog, with experiments on the functional correlation between the essential and accessory sexual organs. J. Physiol., 43, 247. 259.

MAUREL D., JOFFRE J., BOISSIN J., 1977. Cycle annuel de la testostéronémie et de la thyroxinémie chez le blaireau européen (Meles meles L.). C. R. Acad. Sci. Paris, Sér. D, 284, 1577-1580.

MOMBAERTS J., 1943. Le sinus urogénital et les glandes sexuelles annexes du hérisson (Erinaceus europaeus L.). Recherches anatomiques, hisłologiques, embryologiques ef expérimentales. Arch. Biol., 55, 393-555.

MORRIS P., 1973. Winter nests of the hedgehog (Erinaceus europaeus L.). Oecologia (Berl.), 11, 299-313.

PENGELLEY E. T., ASMUNDSON S. J., 1974. Circannual rhythmicity in hibernating mammals, 95-160. In PENGELLEY E. T., Circannual clocks, Acad. Press, New York.

POPOVIC V., 1960. Endocrines in hibernation. Bull. Mus. comp. Zool. Harv. Univ., 124, 105-130.

RACEY P. A., 1974. The reproductive cycle in male noctule bats, Nyctalus noctula. J. Reprod. Fert., 41, 169-182.

RACEY P. A., 1978. Seasonal changes in testosterone levels and androgen-dependent organs in male moles (Talpa europaea). J. Reprod. Fert., 52, 195-200.

RACEY P. A., TAM W. H., 1974. Reproduction in male Pipistrellus pipistrellus (Mammalia : Chiroptera). J. Zool., 172, 101-122.

REITER R. J., 1968. Morphological studies on the reproductive organs of blinded male hamsters and the effects of pinealectomy or superior cervical ganglionectomy. Anat. Rec., 160, 13-24.

REITER R. J., 1972. Evidence for refractoriness of the pituitary gonadal axis to the pineal gland in golden hamsters and its possible implications in annual reproductive rhythms. Anat. Rec., 173, 365-371.

RICHOUX J.-P., DUBOIS M.-P., 1976. Détection immunocytologique de peptides immunologiquement apparentés au LRH et au SRIF chez le lérot dans différentes conditions. C. R. Soc. Biol., $170,860-867$. 
ROE J. H., 1934. A colorimetric method for the determination of fructose in blood and urine. J. biol. Chem., 107, 15-22.

SABOUREAU M., 1979. Cycle annuel du fonctionnement testiculaire du hérisson (Erinaceus europaeus L.). Sa régulation par les facteurs externes et internes. Th. Doct. ès sci., Univ. François-Rabelais de Tours, 198 pp.

SABOUREAU M., BOISSIN J., 1978a. Variations saisonnières de la testostéronémie et de la thyroxinémie chez le hérisson (Erinaceus europaeus L.). C. R. Acad. Sci. Paris, Sér. D, 286, 1479-1482.

SABOUREAU M., BOISSIN J., 1978b. Seasonal changes and environmental control of testicular function in the hedgehog, Erinaceus europaeus L., 111-112. In ASSENMACHER I., FARNER D. S., Environmental endocrinology, Springer Verlag, Berlin.

SABOUREAU M., PEYRE A., 1970. Le décalage des activités endocrine et spermatogénétique du testicule au cours du réveil printanier chez le hérisson mâle. C. R. Soc. Biol., 164, 2364-2367.

SABOUREAU M., LAURENT G., BOISSIN J., 1979. Daily and seasonal rhythms of locomotor activity and adrenal function in male hedgehog (Erinaceus europaeus L.) J. interdiscipl. Cycle Res., 10, 249-266.

SAURE L., 1969. Histological studies on the sexual cycle of the male hed gehog (Erinaceus europaeus L.). Aquilo, 9, 1.43.

SCHÜTZ H., 1954. Das verhalten des hodens und nebenhodens bei Igel (Erinac. europ. et rom. L.) während des estrus. I. Anat. Anz., 101, 84-94.

SCHÜTZ H., 1956. Das verhalten des hodens und nebenhodens beim Igel (Erinac. europ. et rom. L.) während des anoestrus. Anat. Anz., 103, 66-78.

SEMPÉRÉ A., 1978. The annual cycle of plasma testosterone and territorial behavior in the roe-deer, 73-74. In ASSENMACHER I., FARNER D. S., Environmental endocrinology, Springer Verlag, Berlin.

SETCHELL B. P., WAITES G. M. H., 1964. Blood flow and the uptake of glucose and oxygen in the testis and epididymis of the ram. J. Physiol. London, 171, 411-425.

SHORT R. V., MANN T., 1966. The sexual cycle of a seasonally breeding mammal, the roebuck (Capreolus capreolus). J. Reprod. Fert., 12, 337-351.

SKOWRON S., ZAJACZEK S., 1947. Modifications histologiques des glandes endocrines durant le cycle annuel chez le hérisson. C. R. Soc. Biol., 141, 1105-1107.

SMIT-VIS J. H., AKKERMAN-BELLAART M. A., 1967. Spermiogenesis in hibernating golden hamters. Experientio, 23, 844-848.

SUOMALAINEN P., 1953. Untta talvikorroksen fysiologiasta. Suom. Tiedeakat. esifelmäl pöytäk., 138149.

VENDRELY E., GUÉRILLOT C., DA LAGE C., 1972. Variations saisonnières des cellules de Sertoli et de Leydig dans le testicule du hamster doré. Ełude caryométrique. C. R. Acad. Sci. Paris, Sér. D, 275, 1143-1146.

WALHOVD H., 1973. Observationer of pindsvin vinteren 1972-73. Flora Fauna, 79, 66-68.

WALHOVD H., 1975. Winter activity of Danish hedgehogs in 1973-74, with information on the size of the animals observed and location of the recordings. Natura jullandica, 18, 53-61.

WIMSATT W. A., 1969. Some interrelations of reproduction and hibernation in mammals, 511-549. In WOOLHOUSE A. H. W., Dormancy and survival, University Press, Cambridge. 